УДК 172: 304.9

DOI: $10.18101 / 1994-0866-2019-2-83-88$

\title{
УТОПИЯ И УТОПИЧЕСКИЕ ИДЕИ В СОЦИАЛЬНОЙ РЕАЛЬНОСТИ
}

\author{
(C) Бальчиндоржиева Оюна Баировна \\ доктор философских наук, доцент, \\ Бурятский государственный университет им. Д. Банзарова \\ Россия, 670000, г. Улан-Удэ, ул. Смолина, 24а \\ E-mail: baoyu2008@yandex.ru
}

\section{(C) Жамьянов Эрхито Баирович}

аспирант, Бурятский государственный университет им. Д. Банзарова Россия, 670000, г. Улан-Удэ, ул. Смолина, 24а

E-mail: erhito@bk.ru

\begin{abstract}
Авторы статьи рассматривают феномен социальной утопии под углом зрения социального познания и социального теоретизирования, а также практической реализации утопических идеалов в обществе. Перед авторами не стояла задача исследования семантических сдвигов в определении термина «утопия». Используя подход, разработанный Э. Я. Баталовым и другими отечественными философами в области исследования генезиса, развития утопии, ее форм, типов утопического сознания, авторы выделяют и подвергают анализу такие аспекты утопий, как рационализация и технизация. Утопии и утопические идеи функционируют в общественном сознании, играя немаловажную роль в социальной реальности, особенно в кризисные, предреволюционные или революционные периоды. Западные утописты предлагают рациональные формы совместного бытия людей, ищут пути формирования идеальных общественных отношений, обосновывают такие ценности, как свобода, равенство, человеческое достоинство.
\end{abstract}

Ключевые слова: социальная утопия; утопические идеи; утописты; Т. Мор; техноутопии; диджитопии; социальное познание; современное общество.

Для цитирования:

Бальчиндоржиева О. Б., Жамьянов Э. Б. Утопия и утопические идеи в социальной реальности // Вестник Бурятского государственного университета. Философия. 2019. Вып. 2. С. $83-88$.

Утопия, являясь одним из способов социального познания и социального теоретизирования, зачастую становится важным фактором духовной жизни общества. Необходимость в них нарастает в периоды социальных трансформаций, в кризисные периоды. Оказавшись в ситуации выбора, общество осознает необходимость поисков должного социального идеала, «новых» ценностей, форм управления и т. д. В разные периоды могут приобретать значение такие ценности, как спокойствие, умиротворение, равновесие, гармония, общее благо или, наоборот, прогресс, свобода, права человека и личности. Утопии позволяют рассматривать диалектику общественного развития в категориях реального и должного, абсолютного и относительного, имеющегося и желаемого, возможного и ожидаемого.

Многие зарубежные и отечественные авторы указывали на издержки утопий и утопизма. Так, К. Поппер полагает, что утопическая мысль enmasse - элитаристская и авторитарная, противоположная идеалам и разрушающаяся в услови- 
ях «открытого общества» $[1$, с. 2,13$]$. Подобные обвинения убедительно опровергаются Б. Гудвином, который в своем труде приводит таблицу систем ценностей утопизма, либерализма и современного западного государства [2, с. 299], которая показывает двойственность и ложность оснований «либеральной» критики утопизма [3].

Однако утопические идеи в процессе своего развития выражали уникальные признаки той или иной эпохи. Более того, в утопиях отражались основные «интересы сменяющих друг друга на исторической арене общественных классов» $[4$, c. 26]. Многие авторы считают действительным началом утопического дискурса эпоху Ренессанса. Частично соглашаясь с ними, рассмотрим вопрос о том, какие актуальные проблемы социально-экономического и политического развития того периода нашли свое отражение в утопии Т. Мора.

«Т. Мор не только создал в "Утопии" впечатляющую картину хозяйственного и политического развития общества Англии XVI в., но и показал социальные последствия экономических изменений в связи с первоначальным накоплением капитала, что выразилось в массовой экспроприации и обнищании тысяч мелких крестьян-держателей. Вместе с тем Мор дал глубокую критику современного ему социально-экономического и политического строя Англии и попытался вскрыть главную причину социального неравенства и эксплуатации трудящихся масс. В этом смысле «Утопия» Мора была невиданным по силе и страстности протестом, как против огораживаний, так и против социально-политического строя, основанного на частной собственности и эксплуатации... Наряду с анализом социально-экономического развития Англии начала XVI в. T. Мор в «Утопии» подверг острой критике внешнюю и внутреннюю политику тюдоровского абсолютистского государства (налоговую систему, образ жизни дворянства и духовенства и т. д.)... Он подвергал критике и сложившуюся систему международных отношений в Европе того времени» [5, с. 14-30].

В эпоху Просвещения утопия не только возрождается, она видоизменяется. С одной стороны, это все еще описание идеального государства (некоего места, города или острова, которое находится в еще неизученных или недоступных пока регионах). С другой стороны, сам термин становится семантически более разнообразным, а утопические ценности более многозначными.

B XVIII в. прошло важнейшее изменение: утопия оказывается связанной с историческим оптимизмом, а сам термин стал многозначным:

1) воображаемая страна;

2) идеальное государство;

3) идеальное правительство;

4) литературный жанр (путешествие в совершенную страну);

5) страна всеобщего счастья [6, с. 16].

Таким образом, в эту эпоху типология утопий становится гораздо более разнообразной, к современной эпохе это разнообразие увеличилось еще более. Однако в данном исследовании мы основное внимание уделяем таким формам, как «теоретическая концепция или гипотеза, составляющая часть более широкой теоретической структуры» и «политическая декларация, манифест или программа» [4, с. 35-37]. В меньшей степени - утопиям в форме литературного жанра, футурологического прогноза, коммунитарного эксперимента [4, с. 37-38]. 
Опираясь на анализ эволюции утопий, проведенный Д. Е. Мартыновым, отметим, что в XIX в. (веке пара и электричества) утопические идеи трансформировались в «политические проекты государственного устройства и социальные теории» [7, с. 16], уже прямо влияющие на социальную реальность. Произошла мощная «политизация» термина, который стал даже синонимом социализма [7, c. 16].

Здесь необходимо отметить, что К. Маркс остро критиковал утопический социализм и избегал разработки этической теории. Отношение Маркса к этим двум вопросам обсуждается отдельно в литературе. Именно преданность Маркса научному социализму обосновывает его критику. Однако существует мнение, что любая попытка примирить марксизм с этикой должна быть утопической по своей природе [7, с. 131].

Впоследствии многие авторы также подвергали сомнению и критике идеи утопистов. Однако «если обратиться к той же "Утопии", к другим проектам, которые воспринимаются на уровне рациональной интуиции как утопические, "Государству" Платона, "Городу солнца" Кампанеллы, "Путешествию в Икарию" Кабе, "Взгляду назад" Беллами, "Вестям ниоткуда" Морриса, к сочинениям Фурье, Оуэна и ряда других авторов, оставивших заметный след в истории утопии, то нельзя не заметить, что многие грани воплощенных в них идеалов получали — раньше или позднее - практическую реализацию» [8].

Э. Я. Баталов, исследуя генезис и развитие американского утопического сознания, а также утопическую традицию США, заявляет о том, что хоть «Америка не дала миру выдающихся утопистов... Соединенные Штаты оказались "полигоном", на котором испытывались (с большим или меньшим успехом) проекты, созданные в "лабораториях" Оуэна, Фурье, Кабэ и других европейских утопистов» $[4$, с. 6$]$.

Многие политики понимали или интуитивно чувствовали, какой политический заряд несут в себе утопии, и нередко стремились использовать их для осуществления своих целей. В этом, очевидно, одна из причин, почему утопия в $\mathrm{XX}$ в. Занимает прочное место в арсенале средств идеологического и психического воздействия на массы [4, с. 29-30].

В социальной деятельности реформаторов и политиков также проявляется влияние утопической мысли. В качестве классического приводится пример, на который ссылаются едва не все историки утопий - влияние «Океании» Дж. Гаррингтона на формирование взглядов некоторых американских «отцовоснователей», получивших отражение в основополагающих документах американской революции [4, с. 49].

При этом необходимо осознавать ту особенность, которая характерна для социальных утопий, созидающих желаемое общество будущего на основе произвольно конструируемого социального идеала. Маркс же предлагал выводить социальный идеал из практики, из реально существующих отношений. Действительно, как уже отмечалось, проекты практической реализации утопий, существующих в теоретической форме (лозунги, программы, проекты), зачастую проваливались сразу или выхолащивались в процессе реализации, некоторые в какой-то мере осуществлялись [4, с. 78].

Одними из основных особенностей утопий начиная с XVII в. являются рационализация и технизация. Для данной эпохи были характерны вера в торжество 
разума, в возможности машин освободить людей от тяжкого труда, привести общество в лучшее будущее. Утопическое сознание рисует картину экономического и политического освобождения человека.

Ярким примером может служить уже «Новая Атлантида» Ф. Бэкона, в которой опыты, проводимые учеными (с растениями, почвами, химическими веществами, светом, излучением, температурой, звуками, ароматами, механическими приспособлениями и т. д.), и полезные открытия делают жизнь бенсалемцев счастливой и благополучной. На Бенсалеме царят любовь, дружба и уважение к себе. В основе же всего благополучия, как пишет Бэкон, «познание причин и скрытых сил вещей; и расширение власти человека над природою, покуда все не станет для него возможным» [9]. Однако, как мы понимаем, сами по себе научнотехнический прогресс и культ разума не могут сделать жизнь общества лучше и счастливей. Как верно отметили Т. Адорно и М. Хоркхаймер в своей работе «Диалектика Просвещения», наше стремление получить власть над природой привело к еще большему отчуждению от всего того, на что наша власть распространяется [10]. Современное общество более чем ясно осознало все последствия «диалектики Просвещения» - экологический кризис, массовизация личности, нарастание отчуждения, социальная аномия и т. д.

Новым типом утопии становятся технократические утопии. Другими словами, видение будущего рассматривается в ракурсе научного и технологического развития человечества. Техноутопизм занимает значительное место и в современном дискурсе наряду с «цифровыми» утопиями («диджитопии»). В западной аналитической литературе широкое распространение получили оценки перспектив сращивания стратегий технологического и информационного развития общества.

По выражению Э. Я. Баталова, утопия удваивает социальную реальность, надстраивая над ней вымышленный мир и «именно установка на произвольное конструирование идеала лежит в основе утопического творчества» [4, с. 18]. Данное утверждение становится еще более актуальным для современного общества. Современность вряд ли может рассматриваться вне ее коммуникативной, информационной и медиальной характеристик. Знакомые коммуникационные средства массовой информации, такие как телевидение, интернет и телефоны, объединяются в «конвергентные» коммуникации и стимулируют развитие новых услуг, новых продуктов и даже новой экономики. Доминирование информационных технологий и информации в современном мире, надстраивание виртуальной реальности включает в себя и пространство для функционирования современных цифровых утопий. «Современная научная фантастика представляет множество утопических сюжетов, где присутствует множество сценариев технологического улучшения и совершенствования человеческой природы и жизненного уклада как такового, либо же дистопические предостережения, воплощающиеся в пессимистических образах будущего» [11, с. 47]. Мы полагаем, что можно согласиться с утверждением Т. Б. Медведевой «мы являемся сегодня современниками становления очередной версии утопического проекта, порожденного западной культурной традицией» [11, с. 49]. «Современные создатели утопий анализируют проблемы ранее не поднимавшиеся, в частности взаимоотношения человека с техникой, виртуальной реальностью» [12, с. 122]. 
В условиях современного дискурса утопии не вызывает сомнения семантическая многозначность термина «утопия», вариативность методологических приоритетов, но есть и общее понимание того, что склонность к созданию детализированных до абсурда картин светлого будущего должны подвергаться справедливой критике. Негативное отношение к созданию образцово-показательных социальных общин в настоящее время на все лады отражено в современных антиутопиях и дистопиях. Идеал должен быть соответствующим образом дистанцирован от реальности. Фундаментальными ценностями в современности становятся человеческая жизнь и достоинство, ненасилие, открытость, а основными характеристиками желаемого идеального общества - динамичность, альтернативность, нелинейность.

Лumepamypa

1. Popper K. The Open Societyand Its Enemies. Vol. 1. L.: Routledge and Kegan Paul, 1962. $421 \mathrm{p}$.

2. Goodvin B. Utopia Defended against the Liberals // Political Studies. 1980. Vol. XXVIII, № 3. P. 384-399.

3. Мартынов Д. Е. Утопизм и либерализм: основания критики и опыт апологии [Электронный ресурс] // Электронный научный журнал КубГАУ. 2006. № 24(8). URL: http://ej.kubagro.ru/2006/08/pdf/22.pdf (дата обращения: 24.04.2019).

4. Баталов Э. Я. Социальная утопия и утопическое сознание в США. М.: Наука, 1982. 337 c.

5. Осиновский Н. Томас Мор. М.: Наука, 1978. 336 с.

6. Raptis B. K. On the Possibility of Marxist Ethics // Bey tulkhikme - an international journal of philosophy.2018. N 8(1). P. 131-155.

7. Мартынов Д. Е. Западные социальные утопии и проект «Великого Единения» Кан Ю-вэя в общественно-политическом развитии Китая: автореф. дис. ... д-ра ист. наук. Казань, 2011.46 с.

8. Баталов Э. Я. В мире утопии. Пять диалогов об утопии, утопическом сознании и утопических экспериментах [Электронный pecypc]. URL: http://www.marsexx. ru/utopia/batalov-v-mire-utopij.html\#221 (дата обращения: 11.04.2019).

9. Бэкон Ф. Новая Атлантида [Электронный pecypc]. URL: https://volsu.ru/upload/.../7f0/grceiglucu\%20scbsvssiub\%20ixozvtwjwradidhrkt.doc (дата обращения: 30.04.2019).

10. Адорно Т., Хоркхаймер М. Диалектика Просвещения [Электронный ресурс]. URL: https://gtmarket.ru/laboratory/basis/5521/5522 (дата обращения: 30.04.2019).

11. Медведева Т. Б. Технологическая утопия и формы ее репрезентации в современной культуре: техно-прогрессивизм, трансгуманизм и цифровая утопия // Научные ведомости Белгородского государственного университета. Сер. Философия. Социология. Право. 2011. Т. 18, № 20(115). С. 45-61.

12. Захарова К. Н. Социальная утопия современного общества // Вестник Нижегородского университета. Сер. Социальные науки. 2012. № 2(26). С. 119-124. 


\section{UTOPIA AND UTOPIC IDEAS IN SOCIAL REALITY}

Oyuna B. Balchindorzhieva

Dr. Sci. (Philos.), A/Prof.,

Dorzhi Banzarov Buryat State University

24a Smolina St., Ulan-Ude 670000, Russia

E-mail: baoyu2008@yandex.ru

\section{Erkhito B. Zhamyanov}

Research Assistant,

Dorzhi Banzarov Buryat State University

24a Smolina St., Ulan-Ude 670000, Russia

E-mail: erhito@bk.ru

The article considers the phenomenon of social utopia from the perspective of social cognition, social theorizing, and practical realization of utopian ideals in society. We did not aim at studying semantic shifts in the definition of the term "utopia". Using the approach developed by E. Ya. Batalov and other domestic philosophers in the field of genesis and development of utopia, its forms, types of utopian consciousness, we singled out and analyzed such aspects of utopias as rationalization and technicalization. Utopias and utopian ideas play an important role in social reality, especially in crunch, pre-revolutionary or revolutionary periods. Western utopians offer rational forms of human being together, seek ways to form ideal social relations, substantiate such values as freedom, equality, human dignity. Keywords: social utopia; utopian ideas; utopians; Th. More; techno-utopias; digital utopias; social cognition; modern society. 